\title{
A Rare Intracranial Mass of Childhood; Menengioma
}

\author{
Çocuklukta Nadir Görülen İntrakraniyal Bir Kitle; Menenjiyom
}

Nurdan Gocgun, (D) Turkan Ikizceli, (D) Behice Kaniye Yilmaz, (D) Yildiray Savas, (D) Rustu Turkay

Sağlık Bilimleri Üniversitesi, Haseki Sağlık Uygulama ve Araştırma Merkezi, Radyoloji Anabilim Dalı, İstanbul

\begin{abstract}
Meningioma is the most common extra parenchymal brain tumor in adults, originating from arachnoid cap cells in the brain, and is very rare in childhood. As pediatric meningiomas are rare, they have different and challenging epidemiological, radiological, and histopathological features than adults. We aimed to share a very rare case of meningioma in a 7-year-old girl presenting with sudden vision loss and seizures in the light of the literature.

ÖZET

Menenjiyom, erişkinlerde beyindeki araknoid kapak hücrelerinden kaynaklanan en yaygın ekstra parankimal beyin tümörüdür ve çocukluk çağında çok nadirdir. Pediatrik menenjiyomlar nadir olduğu için yetişkinlere göre farklı epidemiyolojik, radyolojik ve histopatolojik özelliklere sahiptirler. Bu yazıda, ani görme kaybı ve nöbetler ile başvuran 7 yaşında bir kız çocuğunda nadir görülen bir menenjiyom olgusunu literatür eşliğinde sunulmuştur.
\end{abstract}

\section{Key Words:}

Pediatric brain tumors, Atypical meningioma, Supratentorial tumors, Childhood tumors

\section{Anahtar Kelimeler:}

Pediatrik beyin tümörleri, Atipik menenjiyom, Supratentoryal tümörler, Cocukluk că̆l tümörleri

\section{INTRODUCTION}

Primary central nervous system tumors are in second tumors after lymphoproliferative diseases among childhood masses. Its incidence is 3/100 thousand, but its mortality is high. Pediatric supra and infratentorial brain tumors are seen with the same frequency throughout childhood; newborn-up to 3 years old supratentorial; It tends to be localized infratentorial at 410 years of age $(1,2)$. Supratentorial extra axial masses are rare compared to intraxials, and arachnoid cyst (1\%), pineal (3-8\%) and choroid plexus (0.5\%) region tumors can be counted. Meningiomas are brain tumors that are very rare in childhood $(3,4)$.

\section{CASE}

A 7-year-old female patient was admitted to the emergency room with a sudden loss of vision and fainting. There wasn $\wedge$ t any trauma and operation history. Her neurological examination was unremarkable, except for a seizure clinic. After the physical examination, she was directed to the radiology clinic for non-contrast brain tomography (CT) imaging. Laboratory findings were nonspecific.

CT findings; spontaneous hyperdense mass lesion located on the left parafalcine, which about $2 \mathrm{~cm}$ in diameter, diffuse hypodensity of adjacent brain parenchyma extending to the left half of the vertex compatible with edema (Figure 1a). There wasn $\wedge t$ any hemorrhage in the brain parenchyma and calcification in the mass. The findings of the patient's contrastenhanced brain magnetic resonance imaging (MRI) are; there was an extra-axial mass lesion with heterogeneous intensity (Figure 2a, b, c) located in the inferior of the cingulate gyrus and left parafalcine, sitting on the dura with a broad base, accompanied by the dural tail in contrast-enhanced series (Figure 2d). However, the mass was not homogeneous, and it had a different intensity in the central component (Figure 2a). It was smooth-lobule contoured and had non-contrasted focal areas in the post-contrast series (Figure 2d).

The patient was immediately taken to the operation after the appropriate medication of seizure clinic. In the patient -who did not develop any post-op complications. It was observed that the mass was removed without residual in the control CT and brain MRI which was taken within 24 hours, but the adjacent intraparenchymal edema persisted (Figure 1b).

\section{DISCUSSION}

Meningiomas originate from arachnoid cap cells, constitute $15 \%$ of all intracranial masses in adults, and $0.4-4 \%$ in children and are rarely seen in childhood.

Pediatric meningiomas have different epidemiological, radiological, and histopathological features than adults. Male gender, cystic nature, the tendency to intraventricular localization, and the absence of dural enhancement are some of these.

Mass sizes are larger than adults at diagnosis; patients are more sensitive to intraoperative hypovolemia. $(5,6,7)$. Meningiomas, which are not accompanied by dural enhancement, are different from adults and are common in children (13-27.7\%). The low dural interaction mimics intraparenchymal masses, and the edema around it is inversely proportional to the mass dimensions (8).

\section{Received: 11.06 .2020}

Accepted: 18.06 .2020

Correspondence: Turkan Ikizceli University of Health Sciences Haseki Training and Research Hospital; Adnan Adivar Street, Number:9, 34130, Fatih, Istanbul/TURKEY Email address: turkan.ikizceli@sbu.edu.tr Phone number: +90 532 455-6302

Cite this article as: Gocgun N, Ikizceli T, Yılmaz BK, Savaş Y, Turkay R. A Rare Intracranial Mass of Childhood; Menengioma. Phnx Med J. 2020;2(1):115-117. 


\section{Gocgun et al.}
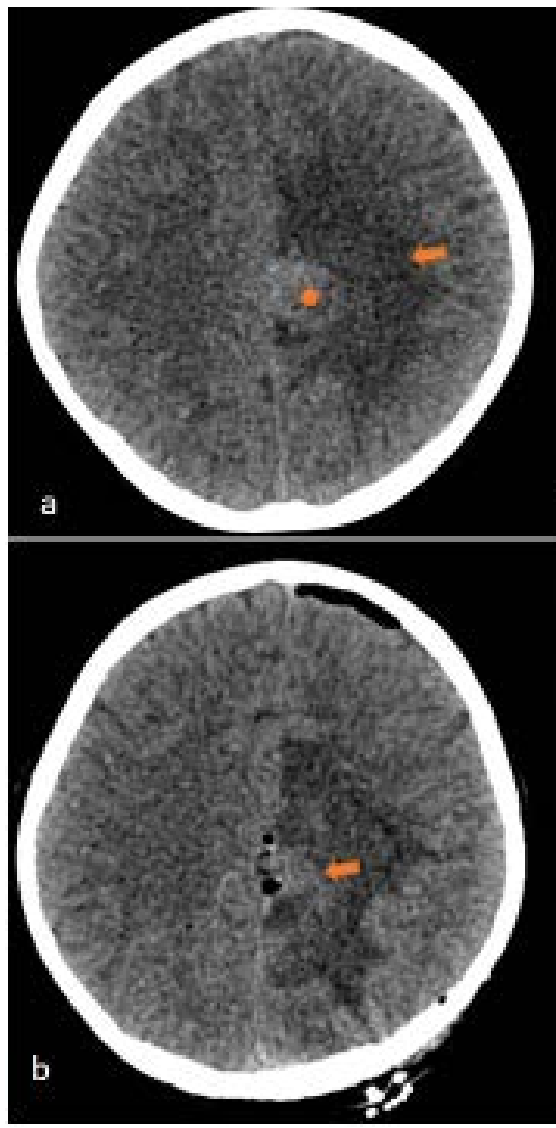

Figure 1:

a) Parafalcine spontaneous hyperdense mass (asterisk) in the preop CT and surrounding hypodense edema (arrow)

b) Parafalcine mass is not observed

in post-op CT, post-op. cavity and air (arrow)
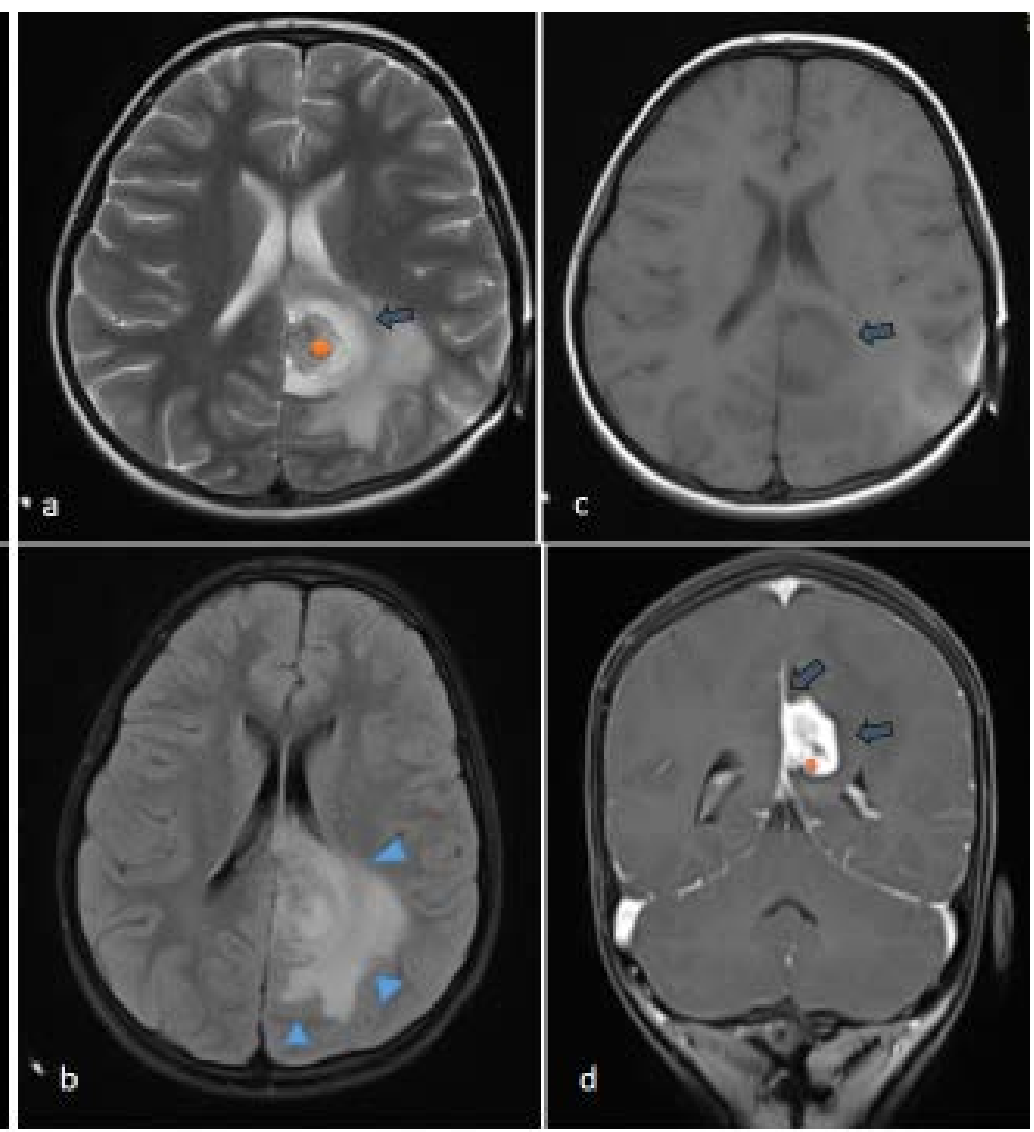

Figure 2:

a) axial T2-Weighted image parafalcine heterogeneous

mass (asterisk), edema around (arrow) b) axial T1WI calcification-free parafalcine mass (arrow) c) Diffuse edema around the mass in FLAIR (arrowheads) d) Coronal contrasted T1Wİ heterogeneous contrasting mass and dural enhancement (arrow), non-contrasting focal areas within the mass (asterisk)
Pediatric meningiomas develop primary-sporadic or secondary to NF2 and radiation exposure. In Huntoon et al.'s study in 2007; 67\% atypical radiological locations (intraparenchymal, intraosseous, intraventricular), 50\% radiological appearance imitating intraxial masses, lack of dural enhancement, $70 \%$ low level of edema of neighboring parenchyma, were reported in 15 sporadic pediatric meningioma patients (9). The histopathological staging of meningiomas with radiologically atypical imaging findings was WHO grade 2 or $3(10,11)$. In our pediatric case, the extra axial parafalcine location of the mass, dural enhancement and diffuse edema in adjacent organs were typical radiological features of meningioma, however, the heterogeneity of mass, smooth-lobule contour, and noncontrasting focal areas in the medial portion of the mass in the post-contrast series were atypical imaging findings. The histopathology of mass was WHO grade2 by atypical pediatric meningiomas in the literature, and non-contrasted focal areas were associated with the microcystic pathological type and cystic natures mentioned in the literature.

Meningioma; It must be considered in the differential diagnosis of pediatric intracranial masses, and the clinician should be assisted in this way in planning the operation.

Conflicts of Interest All other co-authors have no conflicts of interest.

\section{REFERENCES}

1. Paldino MJ, Eric NF, Poussaint TYImaging Tumors of the Pediatric Central Nervous System Radiol Clin North Am. 2011;49(4):589-616.

2. Altekruse S, Kosary C, Krapcho M, et al. SEER Cancer Statistics Review, 1975-2007. Bethesda (MD): National Cancer Institute; April 2010. 


\section{Phnx Med J. July, 2020. Volume 2 No 2}

1. Borja MJ, Plaza MJ, Altman N, Saigal G. Conventional and advanced MRI features of pediatric intracranial tumors: supratentorial tumors. AJR Am J Roentgenol. 2013;200(5):483-503.

3. Smith AB, Rushing EJ, Smirniotopoulos JG. From the archives of the AFIP: lesions of the pineal region radiologic-pathologic correlation. RadioGraphics. 2010; 30:2001-2020.

4. Liu X, Zhang Y, Zhang S, Tao C, Ju Y. Intraparenchymal atypical meningioma in basal ganglia region in a child: case reportand literature review. J Korean Neurosurg Soc 2018; 61:120-126.

5. Munjal S, Vats A, Kumar J, Srivastava A, Mehta VS. Giantpediatric intraventricular meningioma: case report and review of literature. J Pediatr Neurosci. 2016; 11:219-222.

6. Ravanpay AC, Barkley A, White-Dzuro GA, Cimino PJ, Gonzalez-Cuyar LF, Lockwood C, et all. Giant pediatric rhabdoid meningioma associated with a germline BAP1 pathogenic variation: a rare clinical case. World Neurosurg. 2018; 119:402-415.

7. Hong S, Usami K, Hirokawa D, Hideki O. Pediatric Meningiomas: A Report of 5 Cases and Review of Literature.Childs Nerv Syst. 2019;35 (11): 2219-25.

8. Huntoon K, Pluto CP, Ruess L, Boué DR, Pierson CR, Rusin JA, et al. Sporadic Pediatric Meningiomas: A Neuroradiological and Neuropathological Study of 15 Cases. J Neurosurg Pediatr. 2017 ;20(2):141-148.

9. Ravindranath K, Vasudevan MC, Pande A, Symss N: Management of pediatric intracranial meningiomas: an analysis of 31 cases and review of literature. Childs Nerv Syst. 2013: 29:573-582.

10. Alay MT, Yiğin AK, Özdemir F, Gümüş U, Ocak Z, Seven M. Konjenital Sakrokoksigeal Teratomlu Bir Sotos Sendromu Vakası. Anka Tip Dergisi. 2019; 1(1):44-46. 